\title{
Biocompatibility of polyamide 12 intramedullary rod after humeral consolidation in white Plymouth Rock birds ${ }^{1}$
}

\author{
Romim G. Dias², Georgia M. Magalhães ${ }^{3}$, Luís Gustavo G.G. Dias ${ }^{4}$, Jessé R. Rocha², \\ Fernanda G.G. Dias ${ }^{2}$, Andréia C. Facin ${ }^{4 *}$ and Ewaldo Mattos Junior ${ }^{2}$
}

\begin{abstract}
Dias R.G., Magalhães G.M., Dias L.G.G.G., Rocha J.R., Dias F.G.G., Facin A.C. \& Mattos Junior E. 2018. Biocompatibility of polyamide 12 intramedullary rod after humeral consolidation in white Plymouth Rock birds. Pesquisa Veterinária Brasileira 38(10):1909-1912. Faculdade de Ciências Agrárias e Veterinárias, Universidade Estadual Paulista, Campus Jaboticabal, Avenida Prof. Paulo Donato Castellane s/n, Jaboticabal, SP 14883-900, Brazil. E-mail: andreiacfacin@hotmail.com

Technological and tissue engineering have enabled available, biologically inert, and low cost materials to be considered as viable alternatives in the surgical treatment of long bone fractures in birds. The aim of this study was to microscopically analyse osteotomized humerus of birds following the insertion of solid laser-sintered polyamide 12 rods in order to detect foreign body reaction and, thus, verify the bioinert property of the material in the bone fracture environment. Polyamide 12 intramedullary rods were inserted into the osteotomized humerus of 10 birds (white Plymouth Rock) and blocked using $2 \mathrm{~mm}$ diameter cortical screws of varying lengths. The birds were operated at 60 days of age and monitored post-operatively for three months. Animals were euthanized at 150 days old and samples of the operated humerus collected for immunohistochemistry, light and scanning electron microscopy analysis. Results show bone consolidation without rejection of the implant and absence of inflammatory cells. Vascular Endothelial Growth Factor (VEGF) was expressed in the endothelial cells of the blood vessels at the site of the newly formed bone surrounding the implant, indicative of local angiogenesis. There was no bone growth on the surface of the rod; however, the implant did not interfere with the circumjacent bone repair. Thus, the findings of this study corroborate with the literature in characterizing polyamide as a bioinert material and, under the studied conditions, it can be concluded that polyamide 12 intramedullary rod is biocompatible and provides adequate bone consolidation in humeral fractures with no signs of rejection.
\end{abstract}

INDEX TERMS: Biocompatibility, polyamide 12, intramedullary rod, humerus, birds, white Plymouth Rock, biomaterial, bioinert, foreign body, osteosynthesis, rejection.

\footnotetext{
RESUMO: [Biocompatibilidade de haste intramedular bloqueada de poliamida 12 após consolidação óssea umeral em aves Plymouth Rock branca.] Com o desenvolvimento tecnológico e crescimento da engenharia de tecidos, o uso

${ }^{1}$ Received on January 12, 2018.

Accepted for publication on May 7, 2018.

${ }^{2}$ Universidade de Franca (Unifran), Avenida Dr. Armando Salles de Oliveira 201, Parque Universitário, Franca, SP 14404-600, Brazil.

${ }^{3}$ Instituto Federal do Sul de Minas, Rua Muzambinho Km 35, Bairro Morro Preto, Muzambinho, MG 37890-000, Brazil.

${ }^{4}$ Departamento de Clínica e Cirurgia Veterinária, Universidade Estadual Paulista "Julio de Mesquita Filho" (Unesp), Avenida Prof. Paulo Donato Castelane, Jaboticabal, SP 14884-900, Brazil. *Corresponding author: andreiacfacin@hotmail.com
}

de materiais disponíveis, bioinertes e debaixo custo pode ser alternativa viável para o tratamento cirúrgico de fraturas em ossos longos nas aves. 0 objetivo do estudo foi realizar avaliação microscópica óssea após a implantação de haste maciça de poliamida, implantada em úmeros osteotomizados de galinhas para detectar reação do tipo corpo estranho, verificando a propriedade "bioinerte" do material no ambiente de fratura óssea. Foram utilizados 10 galos (Plymouth rock branca) e implantou-se a haste perfazendo o bloqueio das mesmas com parafusos corticais de $2 \mathrm{~mm}$ de diâmetro com comprimentos de acordo com a necessidade. As aves foram operadas aos 60 dias de vida e o acompanhamento pós-operatório ocorreu por três meses. Após a eutanásia, foram realizadas coletas do úmero operado (local de consolidação óssea) paraexame 
histopatológico, imuno-histoquímico e de microscopia eletrônica de varredura. Os resultados demonstraram consolidação óssea, sem presença de rejeição do material, com ausência de células inflamatórias. A neoformação óssea ao redor do implante expressou VEGF (fator de crescimento endotelial vascular) nas células endoteliais dos vasos sanguíneos caracterizando angiogênese no local. Na região de interface de tecido ósseo com a poliamida não foram observadas micro fraturas. Não houve crescimento ósseo na superfície da haste, porém a mesma não atrapalhou o reparo ósseo circunjacente. Assim, esse estudo corrobora com a literatura caracterizando a poliamida como um material bioinerte, e nas condições estudadas pode-se concluir que o uso da haste intramedular de poliamida 12 proporcionou consolidação óssea nesse modelo biológico nesse tipo de fratura, não havendo indícios de induzir rejeição.

TERMOS DE INDEXAÇÃO: Biocompatibilidade, haste intramedular, poliamida 12, consolidação óssea, úmero, aves, Plymouth Rock branca, biomaterial, fratura, osteossíntese, rejeição, corpo estranho, inerte.

\section{INTRODUCTION}

Engineering has been dedicated to developing biomaterials that can be used instead of or as adjuvant in the treatment of lesions in several tissues and organs (Khan \& Peh 2003, Azevedo et al. 2007, Li et al. 2012, Liu et al. 2016). Recently, bone tissue engineering has been used as a new therapeutic approach, aiming at developing and proliferating bone cells by providing substrate for tissue repair at the fracture site (Abdal-hay et al. 2013).

The development of successful orthopaedic implants, such as blocked intramedullary rods, requires adequate levels of biocompatibility, mechanical stability, and bioactivity so that an ideal interface is created between the tissue and the implant (Liu et al. 2016). Biomaterias have physical (Dalby et al. 2002), chemical (Li et al. 2008, Liu et al. 2016), and biochemical factors (Bellis 2011) on their surface that can be shaped and that directly affect the adjacent tissues, generating immediate tissue response in the bone microenvironment.

Thus, the aim of this study was to evaluate the biocompatibility of polyamide 12 , through local tissue response, when used as the main stabilizing agent in humeral osteosynthesis in birds. During the period in which the animals were implanted with polyamide 12 , there were no acute or chronic inflammatory reactions.

\section{MATERIALS AND METHODS}

This study was approved by the Ethics Committee in the Use of Animals (CEUA) of the Universidade de Franca (Unifran), Franca/SP, Brazil (protocol number 041/12).

Ten 45 days old and clinically healthy male white Plymouth Rock birds were used in this study. Details on animal husbandry prior to the study have been detailed by Cherobini (2014). The insertion of the intramedullary rods followed the standard technique described (Wheeler et al. 2004) and adapted to birds Cherobini (2014).

The post-operatory period consisted of daily clinical-orthopaedic evaluation of the operated wing, cleaning of the surgical wound until removal of the synthesised cutis, and meloxicam $\left(0.1 \mathrm{mg} \mathrm{kg}^{-1}\right)$ every 24 hours for four days. Radiography was performed weekly up to 60 days post-surgery. Euthanasia took place at 90 days post-operation and a $10 \mathrm{~mm}$ long humeral fragment, comprising the osteotomy site and consequently the region of bone repair, was collected for analysis.

Histopathology analysis was performed at the Laboratory of Histopathology of the Universidade de Franca (Unifran), Franca/SP, Brazil. Bone fragments were fixed in $10 \%$ buffered formalin, decalcified in $10 \%$ nitric acid solution after 48 hours, and embedded in paraffin. Tissue sections $(4 \mu \mathrm{m})$ were stained with haematoxylin-eosin (HE) and masson trichrome (MT) and analysed under light microscopy.

Scanning electron microscopy analysis (SEM) was performed at the Center for Microscopy of the Universidade Federal de Minas Gerais (CM-UFMG), Campus Pampulha, Belo Horizonte/MG, Brazil. A 5mm sample $(2.5 \mathrm{~mm}$ to each side of the osteotomy line) was collected from each animal and preserved in 3\% glutaraldehyde containing $0.1 \mathrm{M}$ phosphate buffer $(\mathrm{pH} 7.3)$ at $4^{\circ} \mathrm{C}$ for 24 hours. Subsequently, the sample was placed in $0.1 \mathrm{M}$ phosphate buffer $(\mathrm{pH} 7.3)$ at $4^{\circ} \mathrm{C}$ and kept in fixing agent until processed.

Samples were washed in $0.1 \mathrm{M}$ phosphate buffer, post-fixed in $1 \%$ osmium tetroxide (Os04) in $0.1 \mathrm{M}$ phosphate buffer (secondary fixer), and washed again in $0.1 \mathrm{M}$ phosphate buffer. Samples were immersed in $1 \%$ tannic acid in $0.1 \mathrm{M}$ phosphate buffer for 20 minutes, washed, and placed in secondary fixer for 1 hour prior to being washed in distilled water and subsequently dehydrated in increasing alcohol solutions (35\%, 50\%, 70\%, 85\%, 100\%, 100\%, 100\%). Following $\mathrm{CO}_{2}$ critical point drying, the samples were metalized with gold ( $3 \mathrm{~nm})$ for scanning electron microscopy analysis.

Immunohistochemistry analysis was performed at the Laboratory of Immunohistochemistry of the Universidade de Franca (Unifran), Franca/SP, Brazil. Immunohistochemistry was performed using the REVEAL $^{\text {TM }}$ biotin-free detection system conjugated with horseradish peroxidase according to the manufacture's recommendation. VEGF primary antibody was used at concentration of 1:500 and negative controls received $0.5 \%$ BSA instead (antibody diluent). Canine haemangiosarcoma samples were used as positive controls.

Tissue sections were incubated with VEGF primary antibody at 1:500. The immunohistochemistry method used was the REVEAL biotin-free detection system conjugated with horseradish peroxidase (HRP). Antigen retrieval was performed using steam pressure cooker (Electric Pressure Cooker) with EDTA buffered solution (pH 8.5). Negative controls were incubated with antibody diluent $(0.5 \% \mathrm{BSA})$ instead of primary antibody.

Tissue sections $(4 \mu \mathrm{m})$ were incubated at $60^{\circ} \mathrm{C}$ for one hour, de-waxed in xylene, rehydrated in graduated ethanol solutions, and washed in distilled water. Subsequently, antigen recovery by denaturation in humid heat was performed by incubating the samples in pre-heated EDTA buffered solution ( $\mathrm{pH} 8.5$ ) in pressure cooker (Electric Pressure Cooker, model EPC-808BL) for 20 minutes. The samples were washed in distilled water and incubated for $20 \mathrm{~min}$ in $0.3 \%$ peroxide solution (Hydrogen Peroxide Block-Spring) to block endogenous peroxide activity. Following washing in distilled water, the sections were incubated for 5 minutes in TBS 20. Nonspecific sites were blocked with nonspecific reaction blocking solution (protein block Spring DPB-060) for 20 minutes.

The slides were dried and the sections circled using a hydrophobic pen (Pap Pen). Vascular Endothelial Growth Factor (VEGF) primary antibody at a concentration of 1:500 was added to the sections and incubated in humid chamber at $4^{\circ} \mathrm{C}$ for 18 hours. Subsequently, samples were washed thrice in TBS 20 for 1 minute followed by biotin-free antigen detection with a secondary antibody (kit Reveal biotin-free Polyvalent HRP- Spring) for 25 minutes. The slides were washed in Tris $\mathrm{HCl}$ solution and the reaction revealed using 3,3'-diaminobenzidine (liquid DAB-catalogue K3466). Subsequently, 
the slides were washed in distilled water and counter stained with Harris Haematoxylin. The slides were dehydrated in increasing ethanol solutions, immersed in xylene, mounted using Permount (Fisher Scientific), and analysed under light microscopy (Nikon E200, Japan). Each essay contained positive and negative controls.

\section{RESULTS}

Light microscopy revealed similar results for all samples. An amphophylic material (polyamide 12) could be seen in the intramedullary region of the humerus. There was proliferation of highly vascularized connective tissue at the site of insertion of the polyamide 12 rod (from the medullary to the cortical region), which was highly cellular with differentiation into osteoblasts (Fig.1A). The collagen fibres varied from loose to dense and stained blue by Masson Trichrome dye. In the periphery, a differentiated bone matrix had been formed, with osteocytes in gaps and bone marrow development. All well-differentiated bone matrices stained blue by Masson Trichrome (Fig.1B). No inflammatory cell could be seen in the fragments analysed.

Immunohistochemistry analysis revealed strong positive staining for VEGF by the endothelial cells of the blood vessels. All blood vessels in the bone and marrow expressed VEGF, indicating local angiogenesis (Fig.1C). Some osteocytes also stained positive for VEGF. Scanning electron microscopy (SEM) revealed a centralized polyamide rod (intramedullary location) and bone tissue in centrifuge pattern (Fig.1D; magnification $12 \mathrm{X}, 20 \mathrm{KV}, 9 \mathrm{~mm}$ ). At the interface region, the absence of a gap between the bone tissue and the polyamide 12 rod could be clearly noted at $300 \mathrm{X}, 20 \mathrm{KV}, 300 \mu \mathrm{m}$ (Fig.1E); furthermore, at the greater magnification $(300 \mathrm{X}, 20 \mathrm{KV}, 300 \mu \mathrm{m})$ the implant could be seen as a homogeneous dark grey structure followed by an area of marrow and cortical bone (Figure 1F). There was no infiltration of bone tissue in the central region of the

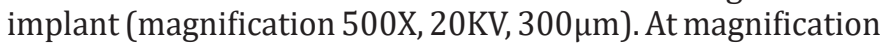
$500 \mathrm{X}(15 \mathrm{KV}, 180 \mu \mathrm{m})$, it was possible to observe areas of marrow containing trabeculae, thus maintaining the porosity of the pneumatic bone (Fig.1G). Under greater magnification $(3000 \mathrm{X}, 15 \mathrm{KV}, 30 \mu \mathrm{m})$ the presence of trabeculae in the bone marrow was even more evident (Fig.1H).

\section{DISCUSSION}

It has been demonstrated that a light material, of easy acquisition, and low cost was efficient in neutralizing the forces present at the fracture site and in providing adequate environment for bone consolidation. According to Hench (1994) and Silva (1998), bioinert materials are those that do not establish interfacial connection with the live host tissue but lead to the formation of a fibrous capsule of variable thickness around the material. Similarly, there was no osteoconduction or osteoinduction in the samples analysed in the present study, and the implant acted only as a support (guide) at the fracture site for bone repair. The presence of osteoblasts in the samples is in keeping with the process of bone repair as these cells induce the formation of osteocytes and, thus, maintains bone tissue function (Aughey \& Frye 2001).

Angiogenesis at the site of the lesion is an important phases of bone repair and VEGF is essential in re-establishing vascular supply during this phase (Keramaris et al. 2008). In the present study, immunostaining for VEGF was observed
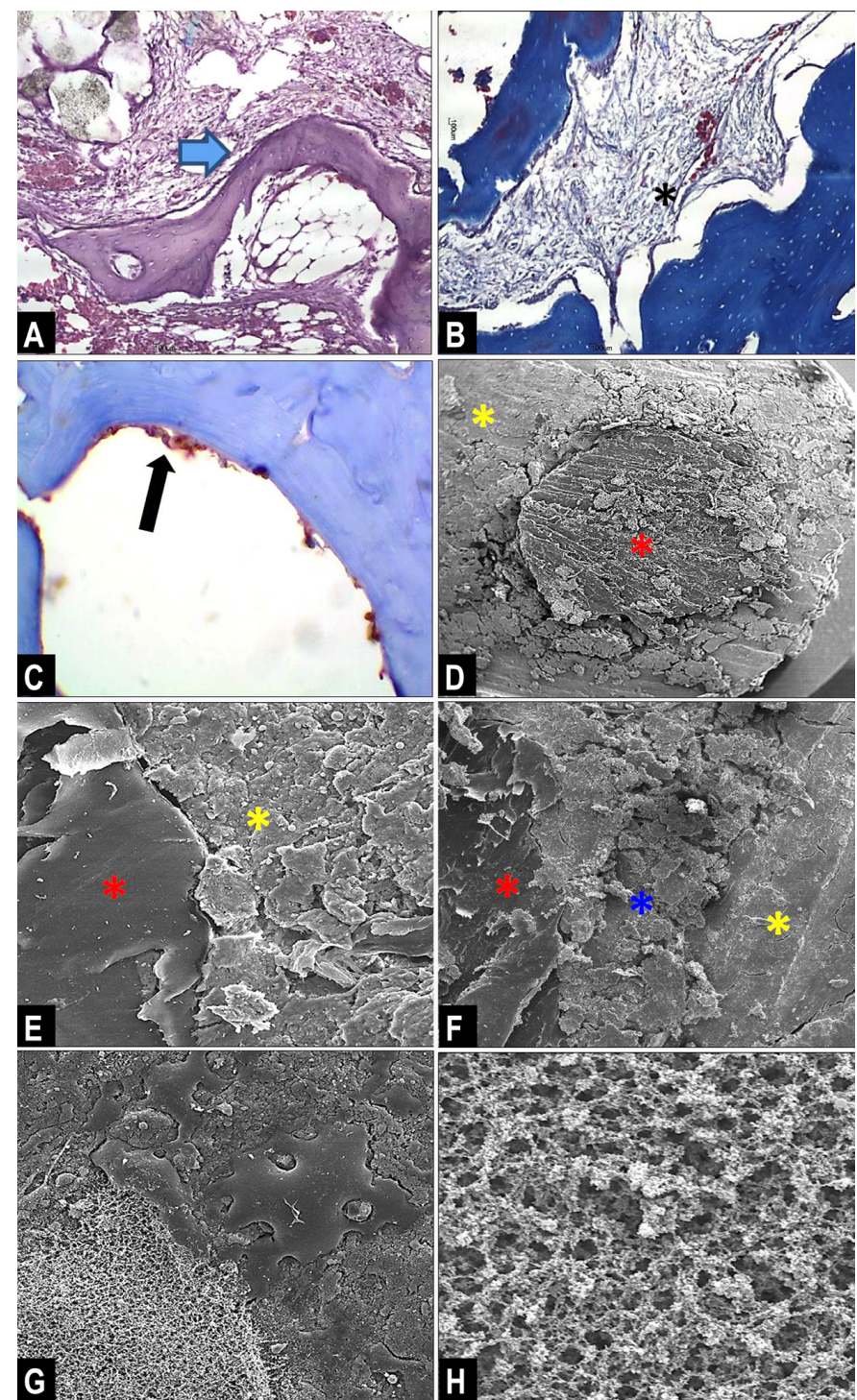

Fig.1. Microscopic images of osteotomized humerus of white Plymouth Rock birds stabilized with sintered polyamide 12 intramedullary rods. (A) Light photomicrography of the bone. Polyamide $12 \operatorname{rod}\left({ }^{*}\right)$ inserted in highly vascularized connective tissue with loose matrix formation (arrow). HE, obj.10x. (B) Light photomicrography of the bone. Connective tissue stained in blue $\left({ }^{*}\right)$. Masson Trichrome, obj.4x. (C) Light photomicrography of VEGF immunostaining in the bone tissue. Cytoplasmic staining of endothelial cells (arrow). REVEAL biotin-free method, DAB detection, Haematoxylin counter-stain, obj.40x. (D) Scanning photomicrography of bone tissue and polyamide 12 rod. Centralized polyamide rod ( ${ }^{*}$ red) and bone tissue in centrifuge pattern (*yellow). Magnification $12 \mathrm{x}, 20 \mathrm{KV}$, $9 \mathrm{~mm}$. (E) Scanning electron photomicrography of bone tissue and polyamide 12 rod. Interface area between the centralized polyamide $12 \operatorname{rod}\left({ }^{*}\right.$ red) and the bone (*yellow). Magnification $300 x, 20 \mathrm{KV}, 300 \mu \mathrm{m}$. (F) Scanning electron photomicrography of bone tissue and polyamide 12 rod. Polyamide rod ( ${ }^{*}$ red), medullar ( ${ }^{*}$ blue) and cortical regions (*yellow) of the bone. Magnification 300x, 20KV, 300 $\mathrm{m}$. (G) Scanning electron photomicrography of bone tissue and polyamide 12 rod. Medullar region of the bone with trabeculae, maintaining the porosity of the pneumatic

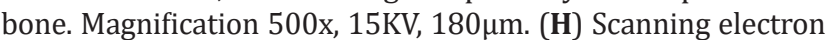
photomicrography of the bone. Medullar region of the bone with

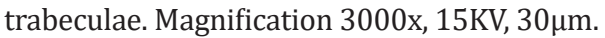


in both endothelial cells and osteoblasts, indicating normal nourishing of the lesion for adequate local repair.

According to Dedavid et al. (2007), SEM enables the evaluation of micro fractures in the interface region, which characterise lesser or greater connecting force between the implant and the bone (Darimont et al. 2002). In this study, there were no micro fractures on the bones or rods, ensuring their stability.

The intensity and duration of an inflammatory response characterise the biocompatibility of a biomaterial. The size, shape, and physic-chemical properties of the biomaterial, in turn, influence this inflammatory response. Once an implant is inserted into an organism it will cause injury, leading to an acute inflammatory reaction, which is followed by chronic inflammation characterized by foreign body reaction and giant cells, and finally local fibrosis (Ratner et al. 1996). During the period in which the animals were implanted with polyamide 12 , there were no acute or chronic inflammatory reactions, characterizing this material as bioinert.

\section{CONCLUSIONS}

Under the studied conditions, polyamide 12 is biocompatible with the bone tissue and does not induce inflammatory reaction.

It can be stated that sintered polyamide 12 was inert for 90 days (bioinert) as it did not show any microscopic signs of foreign body reaction.

Furthermore, there was preservation of the bone trabeculae in the medullar region of the humerus, supposedly favouring aerodynamics in flying birds.

Conflict of interest statement.- The authors have no competing interests.

\section{REFERENCES}

Abdal-hay A., Sheikh F.A. \& Lim J.K. 2013. Air jet spinning of hydroxyapatite/ poly (lactic acid) hybrid nanocomposite membrane mats for bone tissue engineering. Colloids and Surfaces B, Biointerfaces 102:635-643. <http:// dx.doi.org/10.1016/j.colsurfb.2012.09.017><PMid:23107942>

Aughey E. \& Frye F.L. 2001. Comparative veterinary histology with clinical correlates. Manson publishing, Boca Raton, Florida. 285p. <http://dx.doi. $\operatorname{org} / 10.1201 / \mathrm{b} 15184>$.

Azevedo V.V.C., Chaves S.A., Bezerra D.C. \& Lia Fook A.C.F.M. 2007. Quitina e quitosana: aplicações como biomateriais. Revta Eletrôn. Mater. Processos 23:27-34.

Bellis S.L. 2011. Advantages of RGD peptides for directing cell association with biomaterials. Biomaterials 32(18):4205-4210. <http://dx.doi. org/10.1016/j.biomaterials.2011.02.029><PMid:21515168>
Cherobini E.P. 2014. Aplicação e avaliação de haste intramedular de poliamida na estabilização de fratura umeral induzida em galos (Plymouth Rock branca): estudo in vivo. Dissertação de Mestrado, Programa de Pós-Graduação em Medicina Veterinária, Universidade de Franca. 37p.

Dalby M.J., Di Silvio L., Gurav N., Annaz B., Kayser M.V. \& Bonfield W. 2002. Optimizing HAPEX (TM) topography influences osteoblast response. Tissue Eng. 8(3):453-467. <http://dx.doi.org/10.1089/107632702760184718> <PMid:12167231>

Darimont G.L.., Cloots R., Heinen E., Seidel L. \& Legrand, R. 2002. In vivo behaviour of hydroxyapatite coatings on titanium implants: a quantitative study in the rabbit. Biomaterials 23(12):2569-2575. https://doi.org/10.1016/ S0142-9612(01)00392-1. PMID: 12033605.

Dedavid B.A., Gomes C.I. \& Machado G. 2007 Microscopia eletrônica de varredura, aplicações e preparações de amostras: materiais poliméricos,metálicos e semi condutores. EDIPUC-RS, Porto Alegre, p.50-60.

Hench L.L. 1994. Biocerramics from conception clinic. J. Am. Ceram. Soc. 74(7):1487-1510.<http://dx.doi.org/10.1111/j.1151-2916.1991.tb07132.x>

Keramaris N.C., Calori G.M., Nikolaou V.S., Schemitsch E.H. \& Giannoudis P.V. 2008. Fracture vascularity and bone healing: a systematic review of the role of VEGF. Injury 39(Suppl. 2):S45-S57. <http://dx.doi.org/10.1016/ S0020-1383(08)70015-9><PMid:18804573>

Khan T.A. \& Peh K.K. 2003. A preliminary investigation of chitosan film as dressing Forpunch biopsy wounds in rats. J. Pharm. Pharm. Sci. 6(1):2026. <PMid:12753727>

Li Y., Budamagunta M.S., Luo J., Xiao W., Voss J.C. \& Lam K.S. 2012. Probing of the assembly structure and dynamics within nanoparticles during interaction with blood proteins. Am. Chem. Soc. Nano 6(11):9485-9495. <PMid:23106540>

Li Z.J., Gu X.N., Lou S.Q. \& Zheng Y.F. 2008. The development of binary Mg$\mathrm{Ca}$ alloys for use as biodegradable materials within bone. Biomaterials 29(10):1329-1344. <http://dx.doi.org/10.1016/j.biomaterials.2007.12.021> <PMid:18191191>

Liu W., Wang T., Yang C., Darvell B.W., Wu J., Lin K., Chang J., Pan H. \& Lu W.W. 2016. Alkaline biodegradable implants for osteoporotic bone defectsimportance of microenvironment pH. Osteoporosis Int. 27(1):93-104. <http://dx.doi.org/10.1007/s00198-015-3217-8> <PMid:26134681>

Ratner B.D. 1996. The engineering of biomaterials exhibiting recognition and specificity. J. Mol. Recognit. 9(5/6):617-625. https://doi.org/10.1002/ (SICI)1099-1352(199634/12)9:5/6\&lt;617::AID-JMR310\&gt;3.0.CO;2-D. PMID: 9174947

Silva V.V. 1998. Síntese e caracterização de compósitos de zircônia-hidroxiapatita. Tese de Doutorado em Química, Instituto de Ciências Exatas, Universidade Federal de Minas Gerais, Belo Horizonte. 190p.

Wheeler J.L., Lewis D.D., Cross A.R., Stubbs W.P. \& Parker R.B. 2004. Intramedullary interlocking nail fixation in dogs and cats: clinical applications. Compendium 26:7. 